\title{
Influence of Profitability on Dividend Pay-out among Deposit- Taking Saccos in Kenya
}

\author{
Solomon Munyoki Kathuo ${ }^{1}$, Oluoch Oluoch ${ }^{2}$, Agnes Njeru ${ }^{3}$ \\ Department of Economics and Finance, Jomo Kenyatta University of Agriculture and Technology, Nairobi, \\ Kenya \\ Email address: skathuo@yahoo.com¹, josephat.oluoch@jkuat.ac.ke², agnes3198@gmail.com³
}

\begin{abstract}
This study explored the influence of profitability on Deposit-Taking Saccos in Kenya. The study was motivated by inconsistency in the ability of Saccos to live up to their promise of paying dividends to members consistently. Many of them pay dividends from unforeseen profits and/or while highly leveraged. These unhealthy dividend practices leave Saccos unable to pay dividends in the long term sustainably, besides exposing them to insolvency. A census study was conducted involving 179 DT Saccos. This study used a cross sectional design to obtain data from all registered DT Saccos in Kenya $(n=179)$ over an eight-year period (2012-2019). Panel data modelling was used. The findings showed that firms were experiencing declining profits during the study period. During the panel period, Saccos failed to improve their ability to generate resources from equity yet, they sustained a high dividend payout. To maintain their dividend payout, the DT-saccos borrowed funds to pay dividends The findings deepen our understanding of the interplay of factors influencing dividend payout in DT-Saccos in Kenya. Small saccos have higher dividend payout compared to large ones. Indeed, small saccos use dividends as a business strategy to retain and attract new members, thereby augment their capital.
\end{abstract}

Keywords: Saccos, Dividends, Performance, dividend payout, Investment opportunity set

DOI: $10.7176 / \mathrm{IKM} / 11-4-10$

Publication date:September $30^{\text {th }} 2021$

\section{Introduction}

The financial crisis of 2007 and 2008 marked the starting point for a domino effect affecting the global economy. The crisis created a difficult business environment among companies that made them take different course actions in order to remain a float. Key among them was the adjustment of dividend payouts to shareholders that was believed to be a shock absorber. Under normal circumstances, the management of a firm will try to keep a stable and growing dividend and they are not eager to decrease the dividends paid since this is generally interpreted as a negative signal. Nevertheless, during the crisis, the trend of stable dividends was abandoned and some companies drastically decreased their dividend payouts while others at the same time increased the dividends. Among the companies that decreased the dividend payouts to the shareholders in the United State of America stock markets increased from 44 in 2007 to more than 500 in 2009 and those that increased dividend payout decreased from 1.900 in 2007 to approximately 700 in 2009 in the same period (Morgan, 2011).

Fama and French (2001) in their study titled Disappearing Dividends: Changing Firm Characteristics or Lower Propensity Pay find a decline incidence in the percentage of dividend paying firms. Despite the increase in the number of quoted firms, they note that the number of dividend paying firms has decreased sharply. Baker and Wurgler (2004a) make similar findings that are in line with those of Fama and French (2001).

Matendechere (2014), in a study on the relationship between dividend payout and performance of SACCOs in Nairobi County; Kenya finds that there is a strong correlation between improvement in key performance indicators and dividend payout in SACCO's. Implying that those SACCOs that have a tendency of paying dividends perform better than those that did not pay dividends.

Samuel and Memba (2016) investigated the causal relationship between governance and dividend payouts among deposit-taking SACCOs. In focus were a sample of 120 board members drawn from 60 deposit-taking SACCOs in Nairobi County. Deployed, as a theoretical model was the signaling, stakeholder's agency, and resource dependency theories. The findings suggest that board with a longer tenure provide higher dividends than boards with shorter tenure. The length of board tenure enables its members to deal with difficult issues, such as debt and equity financing, both of which have consequences on cash flow. 
Mwangi, Mutiso and Kabata (2018) work grew out of a need to fill gaps in knowledge concerning the effect of Cashflow Liquidity on Dividend Payout among Deposit Taking Saving and Credit Cooperative Societies (SACCOs) in Kenya cash flow on performance of deposit-taking SACCOs. Most of the studies had concentrated on listed firms, with some delving very little into cooperatives movements in general. Lintner's Bird in a Hand Theory informed the study. The findings of the study indicated that cash flow is a significant determinant of dividend payout in deposit-taking SACCOs.

\section{Literature Review}

The link between dividend payout and profitability is mentioned in Jensen and Meckling (1976) agency theory which advocates that two parties, namely; the shareholder and the manager are in harmony in their interests. Similarly, Al-Malkawi (2007) in a study on determinants of corporate dividend payout policy in Jordan. Using a firm level panel data of all publicly traded firms at the Amman Stock Exchange for the period spanning 1989 to year 2000. Using dividend payout as a depended variable and agency cost, Ownership, annual share turnover, market to book ratio, market capitalization of common equity, financial leverage ratio, profitability ratio, and taxes as independent variables. By using Tobit specification concluded that there is a positive relationship between size, age, and profitability with dividend payout and negative relationship between signaling device, ownership, and taxes in Jordan on dividend payout.

Rehman and Takumi (2012), examined the determinants of dividend payout ratio for 50 companies that had announced dividend in 2009 at Karachi Stock Exchange (KSE). The effect of Debt to equity ratio, Operating cash flow per share, profitability, market to book value ratio, current ratio and corporate tax on dividend payout ratio were analyzed. The findings of the study indicated that the relationship between debt to equity ratio, profitability, current ratio and corporate tax with dividend payout ratio was positive and significant. While operating cash flow per share and market to book value ratio has a negative relationship with dividend payout ratio. Profitability, debt to equity and market to book value ratios were found to be the significant determinants of dividend payout ratio.

Mehta (2012) examined factors influencing dividend payout in the United Arab Emirates. The sample included 44 firms listed in the Abu Dhabi stock exchange drawn from multiple sectors, between 2005 and 2009, excluding the banking one. The study was the first of its kind to examine the determinants of dividend payout in the UAE. One of the factors in focus in the study was profitability, which was estimated using the return on assets, return on equity, and earnings per share. The data set used contained 149 firm-year observations. The only return on equity had a significant effect on dividend payout, and this effect was positive. Return on assets and earning per share hurt dividend payout, but this effect was not significant.

In Kenya Musiega et al., (2013) conducted a study aimed at establishing the determinants of dividend payout among non-financial firms on the Nairobi Securities Exchange (NSE). A sample of 30 non-financial companies for a duration of five years from 2007 to 2011 was selected. Secondary data was collected from audited financial statements of companies from the NSE website and the websites of non-financial firms. The dividend payout ratio was the dependent variable while independent variables included profitability. The study established that profitability and firms' growth activities were positively correlated to dividend payout.

Amidu and Abor (2006) conducted a study on determinants of dividend payout ratio in 20 listed firms of Ghana Stock Exchange representing 76\% of the total listed firm in Ghana Stock Exchange. Payout Ratio as controlled variable and explanatory variables includes risk, profitability, cash flow, corporate tax, institutional holding, sales growth, and market to book value. The findings of the study indicate that more profitable firms paid more dividends and profitability is positively related to dividend payout and cash flow and taxes are positively related to dividend payout. The study further concluded that is a positive relationship between increase in liquidity and dividend payout and there is negative relationship between dividend payout: with growth, market to book value, risk, and institutional holding. The firms with the earning instability found hard to pay low and no dividends.

Uwuigbe (2013) study investigated the nature of the linkage between financial performance and dividend payout of listed firms at the Nigerian stock exchange. The objective of the study was to examine the effects of financial performance, firm size, financial leverage and board independence on a dividend payout ratio of firms listed at the Nigerian stock exchange market. Purposive sampling technique was used to select fifty (50) firms for the study. The financial records for the period between 2006 and 2011 were used to collect the relevant data. Regression methodology was used for data analysis whereby it was established that the association between dividend payout ratio and firm size, board independence and financial performance was proportional and statistically significant for firms listed at the Nigerian bourse. 
Bulla (2013) sought to determine factors influencing dividend policy of publicly listed companies at the Nairobi Securities Exchange. The specific objectives of the study was to examine how firms' dividend decisions are influenced by current earnings, dividend yield and firm size. The study analysed empirical panel data of annual earnings per share, dividend yield, sales and dividend per share of 40 listed companies over a period of ten years (2000-2010) with 432 observations. The empirical analysis of data tested the validity of an extended lintners dividend model using data from the Nairobi Stock Exchange. Data was analysed using multiple regression. The regression results indicated that the three explanatory variables predicted $17 \%$ of the variation in dividend payout. Accounting earnings was the single most significant variable explaining about $87 \%$ of the changes in the dividend decisions of firms listed at the Securities exchange. Earnings were also significantly positively associated with dividend payout of companies involved in the study. The other two variables (dividend yield and size of firm) contributed marginally - less than $1 \%$ ). However, dividend yield was negatively related to payout although this was insignificant. Firm size was positively significantly associated with dividend payout. On overall, the result supports Lintner hypothesis that current earnings are positively and significantly related to dividend payouts for companies at the NSE.

The purpose of this study was to find out the determinants of dividend policy in financial industry listed in Indonesia Stock Exchange. This study used a panel data analysis method to investigate the determinants of dividend policy (corporate governance mechanism, profitability, systematic risk, firm size, and leverage) in Indonesia Stock Exchange which sample were taken from 17 companies by using purposive sampling technique from the period of 2009-2015. The empirical result shows that profitability, leverage, and institutional ownership have negative impact on the firm's dividend policy. This study revealed that systematic risk, firm size, and board of directors have no impact to the firm's dividend policy.

Ahmed (2015), sought to investigate the determinants of dividend payout policy in the UAE banking sector. The objective of the study was to investigate the impact of liquidity and profitability on the dividend policy in the UAE banking sector, and to examine any kind of variations between Islamic and conventional banks prior and subsequent to the financial crisis. The study analyzes the data of 18 out of the 24 UAE national banks over the period 2005-2012. The dividend payout ratio is analyzed in relation to six liquidity and profitability ratios. The correlation analysis and regression analysis are conducted to analyze the data. The main finding is that the dividend payout ratio has a significant and positive correlation with liquidity but negative and insignificant correlation with profitability. There is a significant variation of the variables in Islamic banks but not significant with the period.

Kitur and Kisaka (2014), analyzed the relationship between profits and dividend payout of commercial banks consistently listed at the Nairobi Stock Exchange for the period 2008 to 2012 inclusive. The objective of the study was to investigate the nature of relationship between dividend payout and profits of commercial banks in Kenya. The independent variables in the study were: liquidity (measured by cash and balances with CBK), profit before tax and inflation (at year end) whereas the dependent variable was dividend payout. Data from the ten listed commercial banks was collected and analyzed using both simple and multiple linear regressions. The key finding of the study is that there is a strong positive significant relationship between profits and dividend payout, no significant relationship between inflation and dividend payout and that there is a negative significant relationship between liquidity and dividend payout.

\section{Research Methodology}

The study was conducted using a cross-sectional survey design. This design is appropriate because it allows for the description of a situation at a particular point in time. It also allows for the participation of a large number of respondents.

The dataset was divided in two dimensions: time series and cross-sectional elements. Time variation was a factor in the statistical mode, with (2012-2019) constituting the panel period. This is because panel data can deal with more complex information as it combines both cross-sectional and time-series data and this leads to the increase in the number of degrees of freedom and thus the power of the test. According to Brooks (2014) panel data reduces the impact of certain forms of omitted variables bias in regression results that can be mitigated through panel data regression. 
The study relied on secondary data obtained from annual financial reports for the period spanning 2012 to 2019 that were available on the Deposit Taking SACCOs website, headquarters of individual DT SACCOs or at SASRA offices in Nairobi.

The raw data was entered into an excel sheet after which it was cleaned and edited. Thereafter the data set was imported to statistical software (SPSS) and analyzed based on the variables of the study which include profitability, financial leverage, investment opportunity set, cash flow structure, dividend payout, as well as SACCO size as a moderator.

The current study employed a panel data regression analysis. This was appropriate for the study because of its ability in considering heterogeneity problems or individual effects in cross-sectional data and in giving more informative data. Both descriptive and inferential statistics were used to analyze the quantitative data. Descriptive statistics describe and summarize the data in a meaningful way using charts, tables, and bars while inferential statistics conclude the analyzed data, thus helping in the making of inferences. Descriptive statistics described the mean frequency counts and standard deviation. Pearson's correlation coefficient examined the relations between the variables under study variance. Findings on the results of the analysis were made and the results generalized on the population of the study.

\section{Findings}

\section{Descriptive Results For Profitability}

The return on equity ratio or ROE is a profitability ratio that measures the ability of a firm to generate profits from its shareholders investments in the company. In other words, the return on equity ratio shows how much profit each dollar of common stockholders' equity generates. Return On Equity (ROE) according to Fahmi (2015) is a ratio that sees the extent to which investments that have been invested are able to provide a return on profits as expected. The study used Return on Equity to estimate profitability. ROE considered the net income and shareholder's equity of SACCOs over panel period. The results are presented in Table 4.1

Table 4.1: Descriptive Statistics for Return on Equity (ROE)

\begin{tabular}{cccc} 
Mean & Median & Minimum & Maximum \\
0.072742 & 0.019145 & 0.0000 & 0.060854 \\
& & & \\
Std. Dev. & C.V. & Skewness & Ex. Kurtosis \\
0.14 & 1.92 & 2.5341 & 4.8563 \\
& & & \\
$5 \%$ Perc. & $95 \%$ Perc. & IQ range & Missing obs. \\
0.0030090 & 0.51515 & 0.031342 & 0 \\
\hline
\end{tabular}

As depicted in table 4.1, investors in DT-SACCOs saw an average of $7 \% \pm 0.14$ on their investments. The least profitable SACCOs had a ROE of about $0 \%$ and the most profitable SACCOs had ROE of about $6 \%$. This figure was below the average ROE for the banking sector. On this score, the profitability of DT-SACCOs was unsatisfactory. Since good ROE ratio would be between 15-20\%. As such, with a ROE OF 0.07, the profitability of the DT-SACCOs arguably falls short of this mark.

By way of comparison to the wider financial sector, this figure was lower than the average ROE for the banking sector. On this score, there is putative evidence the profitability of DT-SACCOs was below industry standards .Then DT-SACCO's profitability was relatively lower than that of banks, hence the ability of SACCOs to draw from internally generated funds to pay dividends was more constrained vis a vis other players in the lending industry. The overall standard deviation was \pm 0.14 . Since this figure was higher than the mean score, this implies variability in dividend payout was larger over time.

On average, the DT-SACCOs had a ROE of $0.07 \pm 0.14$ which means investors in DT-SACCOs saw an average 7 per cent return on their investment. Since the standard deviation was larger than the mean, the median score provided a more reliable estimate of ROE. Since the standard deviation for ROE was 0.14, which was higher than the mean, the median score or interquartile range, it suggests wide variation in DT-SACCOs' capacity to generate income from equity. Thus, SACCO size can be used for understanding better variation in ROE outcomes for DT-SACCOs. With a skewness statistic of 2.53 , the data distribution was highly positively skewed. On this score, use of the interquartile range of 0.03 was a better measure of the average ROE among DT- 
SACCOs, which was about 0.03 or $3 \%$. If ROE is a fundamental determinant of income firms earn, which they apportion as dividends, then DT-SACCO's profitability was relatively lower than that of banks, which is hence the ability of SACCOs to draw from internally generated funds to pay dividends was more constrained vis a vis other players in the lending industry, (Financial Sector Regulations Programme, 2018). In exploring the determinants of SACCO profitability, SACCO size was used as a moderating variable. The differences in ROE based on SACCO size are as follows.
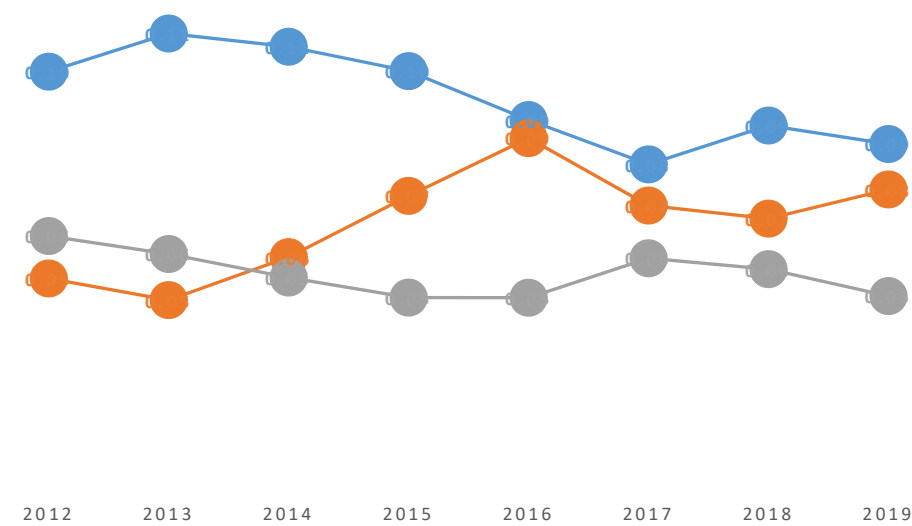

$$
\longrightarrow \text { small } \longrightarrow \text { Medium } \longrightarrow \text { Large }
$$

small Average $=0.1$

medium Average $=0.07$

Large Average $=0.00$

Figure 4.1: Depiction of Mean Scores for Return on Equity 2012-2019 Clustered about Size of DT-SACCO

Figure 4.1 shows that the effectiveness of DT-SACCOs in using local resources to generate income, estimated by return on equity, could not be distinguished easily based on size of DT-SACCOs, more so between medium and large SACCOs. On average, for small-sized SACCOs, ROE was on average at 0.1 , a figure that fell by $10 \%$ over the time under consideration. For medium sized SACCOs, the average score was ROE 0.07, with growth of about 7\% seen between 2012 and 2019. The average score on ROE for large SACCOs was 0.00. No growth was observed for these SACCOs.

Small-scale SACCOs had a slight advantage over medium or large SACCOs concerning ROE. According to the dividend irrelevance theory, dividends are subordinate to the investments a firm makes. For DT-SACCOs, the low rates for ROE suggest a low capacity to increase value either through profits or investments. Small-scale SACCOs had the highest ROE of $10 \%$, and medium-sized ones followed this at 7\%. Large scale SACCOs had an ROE of 0 per cent. However, the profitability of medium-sized SACCOs grew the sharpest during the panel period, with both large and small-size SACCOs seeing a decline in profitability of about $10 \%$. If ROE is a major determinant of profits, which firms partly apportion as dividends, then small firms had the highest capacity to distribute dividends. If so, it would be expected that they would have the highest dividend payout, all things held constant. Moreover, the converse would apply for large scale SACCOs. Given the differences in ROE, and trends over time, the benefit of using SACCO's size as an analytical unit for understanding the phenomenon of dividend payout was evident. The section depicts the graphical representation of dividend payouts concerning return on equity over panel. 


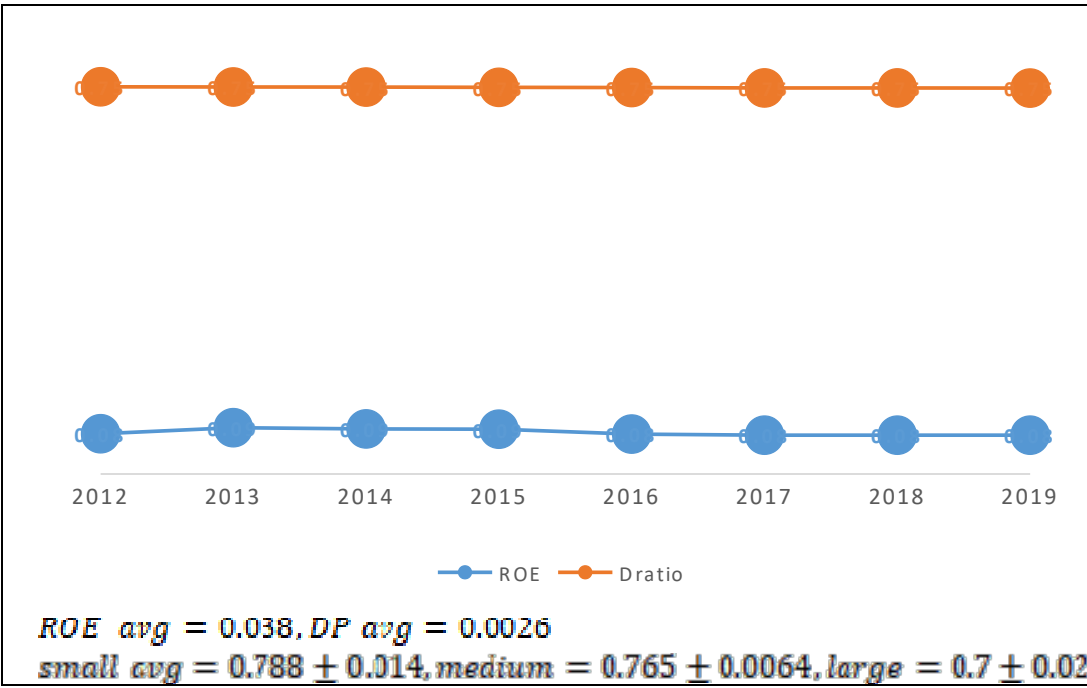

Figure 4.2: Depiction of Mean Scores for Return on Equity

Figure 4.2 depicts the average value for both returns on equity and dividend pay-out between 2012-2019. The average score for return on equity fell by $3.8 \%$ over the panel period. The highest ROE was for the period 2013 2015 , a period that saw the highest dividend payout too. The average dividend payout for small SACCOs was 0.788 , and this figure grew by 1.4 per cent over the panel period. The dividend payout for medium SACCOs was 0.765 over the panel period, and this figure dropped by 0.64 per cent. The dividend payout for large SACCOs was on average 0.7 , and this figure fell by $2 \%$ over the panel period. In the case of DT-SACCOs, the fall in dividends was far slower than it was for ROE. The DT-SACCOs were thus sustaining a dividend policy which seemed out of step with their capacity to generate funds. Small SACCOs had the highest dividend payout, which was the only one that grew over the panel period.

\section{Panel Modelling the Relationship between profitability and Dividend Payout.}

Profitability was measured via ROE and dividend payout by the Dividend payout (DR). The results of the panel model involving return on equity on dividend payout were examined. The results are depicted in table 4.14.

Table 4.14: Panel Model Modelling for the Effect between profitability and Dividend Payout

\begin{tabular}{|c|c|c|c|c|}
\hline \multicolumn{3}{|c|}{ Fixed-effects GLS regression } & Number of obs $=$ & 1253 \\
\hline \multicolumn{3}{|c|}{ Group variable: SACCOs } & Number of groups $=$ & 179 \\
\hline \multirow{2}{*}{\multicolumn{3}{|c|}{$\begin{array}{l}\text { R-sq: within }=0.5204 \\
\text { between }=0.7303\end{array}$}} & Obs per group: $\min =$ & 6 \\
\hline & & & $\operatorname{avg}=$ & \\
\hline \multicolumn{3}{|c|}{ overall $=0.6979$} & $\max =$ & \\
\hline \multirow[t]{2}{*}{ corr(u_i, X) } & $=0$ (assumed $)$ & & $\begin{array}{l}\text { Wald chi2(1) }= \\
\text { Prob }>\text { chi } 2=\end{array}$ & $\begin{array}{l}1602.06 \\
0.0000\end{array}$ \\
\hline & Coefficient & Std. Error & z & p-value \\
\hline const & 0.740816 & 0.000950089 & 779.7 & $<0.0001$ \\
\hline $\mathrm{P}$ & 0.155683 & 0.0130612 & 11.92 & $<0.0001$ \\
\hline
\end{tabular}

Return on equity had a significant effect on dividend payout. The effect was positive in direction. Existing studies have shown that return on equity and dividend payout are correlated (Rehman \& Takumi, 2012). The model seemed strong, accounting for $69.79 \%$ of movement in dividend payout. In predictive terms, a one unit increase in return on equity would occasion a 0.15 increase in dividend payout.

Return on equity would often be associated with the generation of resources that would be used to pay dividends. Increased profitability, as estimated using ROE, would thus avail extra resources, including cash to be available 
to distribute as dividend. Even so, some scholars have found a negative relationship between ROE and dividend payout (Maladjian, 2014; Eriotis, 2005). In the context of the findings of this study, the ROE of DT-SACCOs was generally low and static. These firms had diminished capacity to generate funds from local sources (Ngobe, Simiyu \& Limo, 2013).

Understood this way, SACCOs place investment policies at the expense of dividend payouts (Myers, 2012). Presumably, such SACCOs would apply a residual dividend policy once their profitability increased in the belief that this will assist them to maximise value through investments.

The study sought to establish the effect of profitability on dividend payout.

To determine the relationship, the model $y=\beta_{0}+\beta_{1} X 1+\varepsilon$ was fitted. The regression results were as shown in the table above. The regression results in the table 4.14 show that the effect of profitability on dividend payout was the model fitted was Dividend payout $=0.74+0.15^{*} \mathrm{P}$.

The fitted model implies that for everyone unit increase in the ratio of profitability, dividend pay outs would reduce by 0.15 units.

The study tested the following hypothesis.

$\mathbf{H}_{\mathbf{0}}$ : There is no significant relationship between profitability and dividend payout among the deposit-taking SACCOs in Kenya.

$\mathbf{H}_{1}$ : There is a significant relationship between profitability and dividend payout among deposit-taking SACCOs in Kenya

Since the $\mathrm{p}$-value is significant $<0.001$, the null hypothesis can be rejected and the alternative hypothesis accepted. Profitability have a negative effect on dividend payout among deposit-taking SACCOs in Kenya.

The following section examines the relationship between profitability and dividend payout moderated by SACCO size.

\subsubsection{Panel Modeling of the Moderated Effect of SACCO Size and the Relationship between Profitability and Dividend Payout}

The moderated effect of SACCO size on profitability and dividend payout was examined. This section enumerates the results of the relationship between profitability and dividend payout moderated by SACCO size. Profitability was measured by return on equity while dividend payout was represented by dividend ratio. Specification Tests for moderated effect of SACCO size on the relationship between ROE and Dividend payout is presented.in Table 15.

Table 4.15: Moderated Effect of SACCO Size on the Influence of profitability on Dividend payout

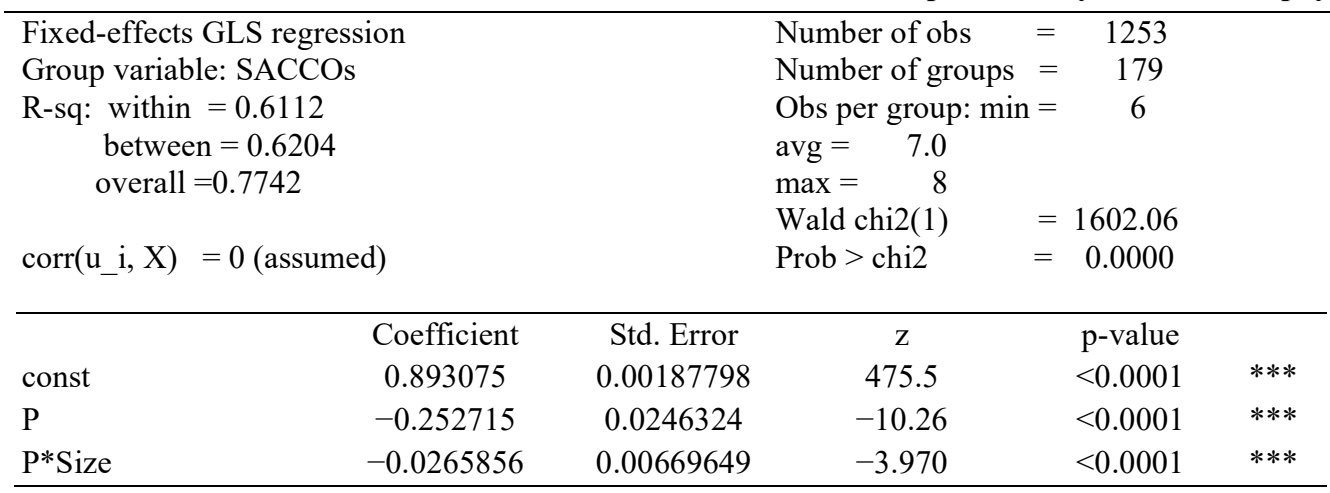

SACCO size had a strong moderating relationship of $77.42 \%$ between profitability and dividend payout. Whether a SACCO was small or big does seems to influence the effect of profitability on dividend payout.

\section{Conclusions}


DT-SACCOs faced diminished capacity to generate profits, which could be distributed to investors. Low ROE would reduce the capacity of any firm to pay dividends. Yet, DT-SACCOs sustained a high dividend payout over the panel period. But firms can maintain dividend payout ratio or increase them even when their profitability has reduced.

For this reason, performance on ROE would merely be indicative. Observed too was that small scale SACCOs had higher return on equity scores compared to medium scale and large-scale ones. Small scale SACCOs too had higher dividend payouts, relative to large scale SACCOs. This finding implies that as firms grow, become more profitable, they would reduce or change their dividend policy and invest larger proportions of net income to support investments.

In hypothesis testing, a significant negative effect was found in relation to the relationship between return on equity and dividend payout. This finding suggests that profitability was a major determinant of dividend payout among DT-SACCOs. SACCO size did not however produce a significant moderating effect in the causal relationship between return on equity and dividend payout. Together, the positive effect of profitability on dividend payout among DT-SACCOs could be attributable to the state of development of SACCOs. Small sized ones were keen to use dividends to attract and retain new members. And this was done to secure their financial viability. For small SACCOs, dividend payout seems to be a response to pressure from members for dividend payouts, which is the reason many of them become members of SACCOs in the first place. For large SACCOs, which were better established than smaller ones, there was a diminished interest in the use of dividends to attract or retain new members. Indeed, managers of these SACCOs seemed keen to invest extra resources in investments, rather than on paying dividends.

Nonetheless, for both small and large scale SACCOs, dividend policies were high and stagnant over the panel period. The larger SACCOs get, based on capital and/or assets, seem to make them be keener on using profits for investments, rather than for dividends. Building the capital base of SACCOs would help them reduce their propensity to engage in unhealthy liberal practices.

\section{Recommendations}

Dividend payout is affected by many components of cash flow. This study did not exhaust all these components. It might be helpful to examine further the relationship between dimensions of cash flow of interest in relation to dividend payout, specifically the effect of cash flow from operating activities as against cash flow from investment activities.

From this study the following directions for future research in growth of SACCOs dividend payout are recommended:

i. Study to be done on effects of board members decisions on Growth of SACCOs dividend payout

ii. Study on capital structure methods and Growth of SACCOs dividend payout.

iii. Study to investigate methods of funds allocation strategy and Growth of SACCOs dividend payout.

\section{REFERENCES}

Aandstad, \& Simon. (2013). Reliability and validity of the soccer specific INTER field test. Journal of Sports Sciences 31(13).

Aasia A, Waqas R. Yasir K, Shaheed Z. A. (2010 Impact of financial leverage on dividend policy: Empirical evidence from Karachi Stock Exchange-listed companies), .African Journal of Business Management Vol. 5(4), pp. 1312-1324, 18 February, 2011 Available online at http://www.academicjournals.org/AJBM ISSN 1993-8233 C2011 Academic Journals Full Length Research Paper.

Abdul R. \& Haruto T. (2012). Determinants Of Dividend Payout Ratio: Evidence From Karachi Stock Exchange (Kse).Journal Of Contemporary Issues In Business Research. Volume 1, Issue No. 1(1), 20-27.

Abor, J. and Amidu, M. (2006)."Determinants of the Dividend payout ratio in Ghana", The Journal of Risk Finance 7, 2, 136-145

Enekwe, C. I., Nweze, A. U. \& Agu, C. I. (2013). The Effect of Dividend Payout On Performance Evaluation: Evidence Of Quoted Cement Companies In Nigeria. European Journal of Accounting, Auditing and Finance Research Vol.3, No.11, pp.40-59.

Adelegan, O. J. (2003). An Empirical Analysis of the Relationship between Cash Flow and Dividend Changes in Nigeria. R\&D Management, 15 (1), 35-49. 
Aduda J, \& Kimathi H. (2011). The Applicability of the Constant Dividend Model for Companies Listed at the Nairobi Stock Exchange. Journal of Financial Studies \& Research (2011) 1-38

Afza T, \& Mirza H. (2011). Ownership structure and Cash-flows as determinants of corporate dividend policy in Pakistan. International Business Research 3, (3), 210-221.

Ahmad, \& Wardani. (2014). The effect of fundamental factor to dividend policy: Evidence in Indonesia Stock Exchange. International Journal of Business and Commerce, 4(2),., 14-25.

Ahmed I. E. (2015), Liquidity, Profitability and the Dividends Payout Policy. World Review of Business Research 5. (2). $73-85$

Ahmeti F, \& Prenaj B. (2015). A critical review of Modigliani and Miller's theory of capital structure. International Journal of Economics, Commerce and Management, 3(6), 914- 924.

Aiken L.S. West S.G. (1991). Multiple regression, testing and interpreting interactions. Newbury Park, CA: Sage.

Aivazian, V. Booth, L. (2003), "Do emerging market firms follow different dividend policiesfrom US firms?", Journal of Financial Research, XXVI (3), 371-87.

Akbar M. \& Baig H.H. (2010). Reaction of stock prices to dividend announcements and market efficiency in Pakistan the Lahore. Journal of Economics, 15 (1) pp.103-125.

Al Zararee, \& Al-Azzawi. (2014). The Impact of Free Cash Flow on Market Value of Firm. Global Review of Accounting and Finance Vol. 5. No. 2. Pp.56-63.

Al-Ajmi J, \& HussainH. (2011). Corporate dividends decisions: Evidence from Saudi Arabia. The International Journal of Economics and Finance 6, (4); 2014, Risk Finance, 12(1), 41-56. 